\title{
On the Ribbing of the Seeds of Ginkgo.
}

\author{
BY \\ MISS M. F. A. AFFOURTIT \\ AND \\ Miss H. C. C. LA RIVIERE. \\ With a Figure in the Text.
}

SOME months ago we received a number of seeds of Ginkgo biloba, $S$ gathered from a tree growing in a garden at Slikkerveer, in the neighbourhood of Rotterdam.

When the thick, fleshy portion of the seeds had been removed, they showed their stony coats; it was remarkable that these were then of very different shapes, even more different than there was reason to anticipate from what is mentioned in the literature. Generally, the seeds seem to be considered as two-sided, but it appears that already A. Braun (1) noticed a difference in the shape of the stones; as he says (p. 738): 'Bei Ginkgo sind die Samen normal zweikantig, zuweilen sehr regelmässig dreikantig.'

E. Strasburger states (2, p. I 5 ) : 'Das Endocarp erscheint, entsprechend der Gestalt des inneren Raumes, scharf zweikantig, seltener dreikantig.'

In G. de Saporta and A. F. Marion we found (3, p. I39): 'Sous un mésotesta charnu, elle renferme un endotesta osseux en forme de coque bi- ou tricarénée.' They also give drawings of a two- and of a threeangled seed (Fig. 69, E, F).

A. W. Eichler (4, p. I09) speaks only of a two-angled form of the stony coat, and figures it (Fig. 68, e, $f$ ).

In the more recent literature the three-angled forms are referred to, as for instance in the following publications: A. C. Seward and J. Gowan (5, p. I24), Carothers (6, p. I 26), and A. Sprecher (7, p. 122). The latter gives also a drawing (Fig. I24) of a three-sided seed, and writes: ' $\mathrm{La}$ plupart des noyaux scléreux ont deux côtés, mais on en trouve assez fréquemment qui en ont trois.'

The relatively large number of seeds we had at our disposal (viz. II7), all derived from a single tree, did not however show such regular forms as might be supposed from the published descriptions, so that we thought them worth placing on record. For not only did they show

[Annals of Botany, Vol. XXIX. No. CXVI. October, 19I5.] 
many gradations between those two regular kinds, i. e. the two- and threeribbed types, but there were also other forms, still undescribed, as far as we are aware.

Whilst nearly half the number were two-angled, even these were not quite regular in form; three kinds of them could be distinguished, though the differences between them were rather slight. In most cases the sides were equally curved, as in the drawings of Eichler and of Saporta and Marion, and as in our own Fig. I, but in some other cases one of them was evidently smaller and much flatter than the other. In these cases the angle which the two ribs made at the summit and base was always $180^{\circ}$, so that the two ribs formed one straight line, as in Fig. I ; but in a third form

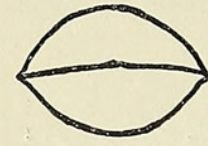

$\mathrm{B}$

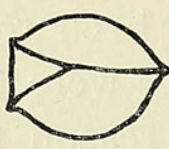

5

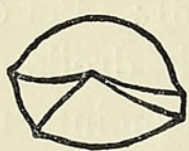

SO

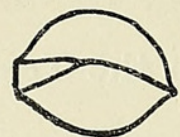

2

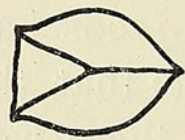

6

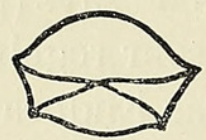

II

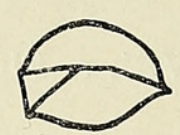

3

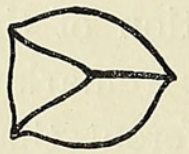

7

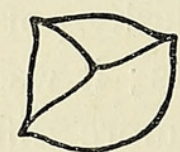

8

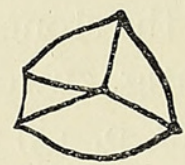

I9

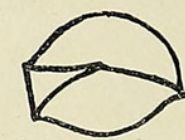

4

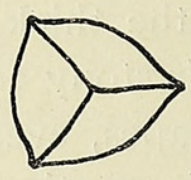

9

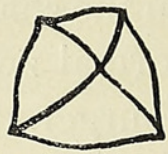

15

Thirteen kinds of seeds of Ginkgo, from which the fleshy coat had been removed ; all seen from the top; natural size. Fig. I. Two-angled seed. Figs. 2-9. Three-angled seeds. Figs. I0-I3. Four-angled'seeds.

this angle was smaller, varying for instance in three cases between $135^{\circ}$ and $160^{\circ}$.

There was also a large number of three-angled seeds, even more than half the total number, but the regular form, as that of our Fig. 9, corresponding also to the figure given by Sprecher, was not so very frequent, as only one-fifth of them all had this shape. The remaining four-fifths were less regular and showed many transitions between the regular two-ribbed and the regular three-ribbed forms. The characteristic shapes were carefully selected and photographed together; they are shown in Figs. 2-8 at their actual size. Their difference is caused by the inequality in size of the three faces, two remaining nearly always equal, the third diminishing gradually in size; by comparing the Figs. 8 and 2, this diminution of the third side is clearly to be seen on the left side of each figure. In Fig. 2 it is so small that this seed approximates to an irregular two-angled one, the 
angle between the lower two ridges of Fig. 2 lying also between $\mathrm{I} 35^{\circ}$ and $\mathrm{I} 60^{\circ}$. Even in seeds like those resembling our Fig. 8 three different forms might be distinguished, although the differences were again not of much importance. A number of them (ten out of nineteen) agreed with the figure, in which we see one face occupying one-half of the stone, the two other the remainder. In seven specimens, however, the two large sides were of equal size, and in the last case (two seeds) the third rib was not entirely developed, as it died out between the base and the apex.

Besides these two- and three-angled forms there were a few four-sided ones, only five in number, four of which are represented in our Figs. IO-I3. The seeds represented in Figs. 10 and II might be regarded as normal two-angled ones (like our Fig. I) with two accessory ridges on one of the faces. The stone of Fig. I 2, on the other hand, looked much more like a nearly regular three-sided one, with a fourth rib on its largest face.

Fig. I 3 was the finest four-angled seed of all, but it was not regular in shape; two of the faces (the lower and the left-hand ones in the figure) were equally large, occupying each one-fourth of the circumference, but in the two others one face was larger and the other smaller than that fourth part.

The fifth and last stone, not represented, resembled both Fig. Io and Fig. 6 , the difference from the latter consisting only in the presence of a fourth ridge on the smallest of its three sides.

The number of the seeds available was evidently too small to permit any general conclusion, but, on the other hand, as it was large enough to give at least an idea as to their frequency, we append the following table:

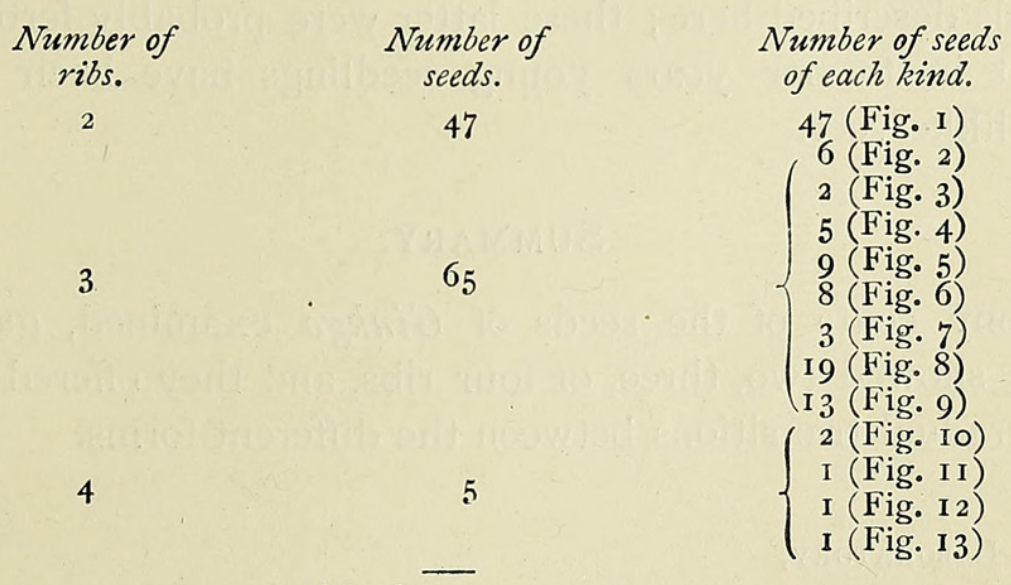

Thus the two-sided seeds did not dominate at all, as there were only 40 per cent. of them; there were even more three-angled ones, i. e. no less than 55 per cent., so that it is hardly possible to conclude anything about their ordinary feature. We can therefore agree entirely with the conclusion of Oliver and Salisbury $(9$, p. 44$)$, who say: "The facts seem to indicate that, whilst the terms "radiospermic" and "platyspermic" have a definite 
use as morphological distinctions, our attitude towards them as criteria of taxonomic importance may require readjustment.'

The differences in number of ribs on the integument and sclerotesta, respectively, of seeds of one and the same species are also recorded in phytopalaeontological literature regarding the seeds of Physostoma and of Trigonocarpus.

As to Physostoma elegans, Oliver mentions $\left(8, \mathrm{p} .8_{3}\right)$ that in the fifty or so specimens that came under observation the number of ribs varied from nine to twelve.

There is no mention made of the occurrence of transitional forms between them, like those we describe for our Ginkgo and which were so frequent, so that our case may perhaps differ in kind from that of Physostoma.

Salisbury speaks about the seeds of Trigonocarpus $(10$, p. 68) relatively to the accessory ribs occurring sometimes on the separate valves, and mostly under vascular bundles of the sarcotesta. Since in Ginkgo, however, no valves occur-the stony coat lacking fissures at the place of the ribsand as vascular bundles are absent from the sarcotesta, those seeds cannot, as it seems to us, be compared with the seeds here described.

In the Botanic Garden at Leyden, several Ginkgo trees are in cultivation; one of them, the largest and a very beautiful tree, may be a male one, although it has never been known to flower. Another one, much smaller and of regular conical form, produced seeds regularly during recent years, but probably they were not fertilized, as we never succeeded in making them germinate. They were also smaller and had a less developed stony coat than the seeds described here; these latter were probably fertilized, as it is reported that in former years young seedlings have been found under the tree at Slikkerveer.

\section{SUMMARY.}

The stony coats of the seeds of Ginkgo examined, gathered from a single tree, showed two, three, or four ribs, and they offered at the same time many gradual transitions between the different forms.

BOTANICAL LABORATORY, UNIVERSITY, LEYDEN. March, I9Ij. 


\section{LITERATURE.}

1. Braun, A.: Monatsberichte der königl. Akad. der Wissensch., Berlin, I4. Okt., I869.

2. Strasburger, E. : Die Coniferen und die Gnetaceen. Jena, I 872 .

3. De Saporta, G., et Marion, A. F.: L'Évolution du règne végétal. Tome i, Paris, $\mathrm{I}^{8} 85$.

4. Eichler, A. W., in A. Engler und K. Prantl, Natürliche Pflanzenfamilien. II. Teil, Abt. I, I889.

5. Seward, A. C., and Gowan, J.: The Maidenhair Tree. Ann. of Bot., vol. xiv, I900.

6. Carothers, I. E.: Development of Ovula and Female Gametophyte in Ginkgo biloba. Bot. Gaz., vol. xliii, I900.

7. Sprecher, A.: Le Ginkgo biloba. Thèse, Genève, I907.

8. Oliver, F. W. : On Physostoma elegans, Will., an Archaic Type of Seed from the Palaeozoic Rocks. Ann. of Bot., vol. xxiii, r9o9.

9. Oliver, F. W., and Salisbury, E. J. : On the Structure and Affinities of the Palaeozoic Seeds of the Conostoma Group. Ann. of Bot., vol. xxv, I9I I.

10. Salisbury, E. I.: On the Structure and Relationships of Trigonocarpus Shorensis, sp. nov. Ann. of Bot., vol. xxviii, 1914. 


\section{$2 \mathrm{BHL}$ Biodiversity Heritage Library}

Affourtit, M. F. A. and La Rivière, H. C. C. 1915. "On the ribbing of the seeds of ginkgo." Annals of botany 29, 591-595.

https://doi.org/10.1093/oxfordjournals.aob.a089565.

View This Item Online: https://www.biodiversitylibrary.org/item/243629

DOI: https://doi.org/10.1093/oxfordjournals.aob.a089565

Permalink: https://www.biodiversitylibrary.org/partpdf/320082

\section{Holding Institution}

Smithsonian Libraries

\section{Sponsored by}

Biodiversity Heritage Library

\section{Copyright \& Reuse}

Copyright Status: Not in copyright. The BHL knows of no copyright restrictions on this item.

This document was created from content at the Biodiversity Heritage Library, the world's largest open access digital library for biodiversity literature and archives. Visit BHL at https://www.biodiversitylibrary.org. 